\title{
Synthesis and Characterisation of First Generation Luminescent Lanthanide Complexes Suitable for Being Adapted for Uptake via the Mannose Receptor
}

\author{
Robert Brooks, Zhangli Du, Glenn Borlace, Douglas Brooks, and Sally Plush \\ Mechanisms in Cell Biology and Disease Research Group, University of South Australia, Reid Building, Frome Road, \\ Adelaide, SA 5000, Australia
}

Correspondence should be addressed to Sally Plush; sally.plush@unisa.edu.au

Received 19 August 2013; Accepted 23 September 2013

Academic Editor: Arturo Espinosa

Copyright (C) 2013 Robert Brooks et al. This is an open access article distributed under the Creative Commons Attribution License, which permits unrestricted use, distribution, and reproduction in any medium, provided the original work is properly cited.

With the aim of directing lanthanide complex uptake via the mannose receptor, a first generation of luminescent lanthanide complexes has been developed with an $\alpha$-D-mannose targeting motif. Four complexes were produced to investigate photophysical properties and determine the effect of the coordinated mannose residue on emission intensity. The free hydroxyls of the $\alpha$-Dmannose residue quenched lanthanide phosphorescence due to their close proximity, though they did not bind the lanthanide centre as observed by $q$-values $\approx 1.0$ for all complexes between $\mathrm{pH} 3$ and 10 . Fluorescent emission was found to vary significantly with $\mathrm{pH}$, though phosphorescent emission was relatively insensitive to $\mathrm{pH}$. This lack of $\mathrm{pH}$ sensitivity has the potential to provide stable emission for the visualisation of the endosome-lysosome system where acidic $\mathrm{pH}$ is often encountered.

\section{Introduction}

Fluorescent probes and stains that recognize cellular compartments have long been used to visualize cell architecture in fixed and, more recently, live cells. To understand receptorligand interaction and internalisation, we need to track each of these components in live cells. Translating this concept into the field of live cell imaging presents a number of complications for probe development. A probe designed for live cell imaging requires long wavelength excitation/emission (to avoid the cell damage that results from low wavelength/high energy light) and a high quantum yield so that small concentrations of probe can be visualised. In addition, high in vivo stability is required, including resistance to any undesirable emission quenching, either by low $\mathrm{pH}$ environments or biological media.

Lanthanide luminescence is an evolving method for cellular visualisation that has recently been applied to provide feedback on dynamic processes in live cells [1]. Stable lanthanide complexes based on europium (Eu(III)), terbium $(\mathrm{Tb}(\mathrm{III}))$, neodymium $(\mathrm{Nd}(\mathrm{III}))$ and ytterbium $(\mathrm{Yb}(\mathrm{III}))$ are particularly attractive as optical probes for in vivo applications as their excitation and emission wavelengths are in the visible or near infrared (NIR) regions. Trivalent lanthanide ion luminescence resulting from inner-shell $4 \mathrm{f}-4 \mathrm{f}$ transitions is observed as characteristic line-like emission bands (10$20 \mathrm{~nm}$ bandwidth), with large Stokes' shifts and long emission lifetimes (ms range) $[2,3]$. These properties support the use of time-resolved detection for cellular imaging, allowing the removal of background autofluorescence in live cells and providing enhanced signal-to-noise ratios when compared to fluorescent analogues [4]. As a result, lanthanide complexes have been developed for the detection of biological analytes including $\mathrm{Ca}(\mathrm{II})$ ions, urate, bicarbonate, and ascorbate [5]. Interestingly, Parker and coworkers have shown that macropinocytosis is the main mechanism of cellular uptake for a range of macrocyclic lanthanide ion complexes. Macropinosome content is then transferred into a range of vesicles and subsequently enters other cellular compartments such as endosomes, lysosomes, cytosol, mitochondria, and the nucleus. Although more than $80 \%$ of these complexes enter the cell via macropinocytosis, a small number were found to be internalised through undefined, alternate pathways. The difference in uptake and site of localisation has been partly attributed to the structure of the antenna group, though neither the pendant arms nor 
the overall charge of the structure was shown to have a significant effect on uptake or cellular localisation. It then follows that the method of internalization and the destination of a luminescent lanthanide complex could be controlled by coupling a lanthanide chelate to a cell surface targeting motif specific for the membrane bound receptor. For disease states that involve impaired receptor-mediated transport, this could be of paramount importance, providing information required to assess and treat patients at the cellular level.

C-type lectin receptors (CLRs) regulate the transport and recognition of mannosylated substrates at a variety of membrane interfaces. Transmembrane proteins in this family include the macrophage mannose receptor (MMR), Endo180, dendritic cell-specific intercellular adhesion molecule3 grabbing nonintegrin (DC-SIGN), DC-SIGN related (LSIGN and SIGNR), and Langerin. These receptors mediate endocytosis and control antigen capture and presentation [6]. Other CLRs, such as the mannose binding protein, surfactant protein $\mathrm{A}$, and surfactant protein $\mathrm{D}$, are collectins that play a role in innate immunity. All CLRs bind mannose and other carbohydrates in a calcium-dependent manner and show high affinity for multivalent glycosides. Mannose receptors (MRs) are highly expressed in endothelial cells and cells of the immune system such as macrophages and dendritic cells, which can be cultured with relative ease. The MR can be effectively targeted by coupling substrates to mannose residues of varying sizes. This technique has been used efficiently to direct the delivery of proteins in enzyme replacement therapy $[7,8]$ and to target drugs/antigens to macrophages and other antigen presenting cells [6]. In human macrophages, the MR delivers substrates to early endosomal compartments and is then recycled to the cell surface [6], whilst in immature dendritic cells, the MR mediates high efficiency uptake of glycosylated antigens [9]. In addition, the structure of the mannosylated ligand regulates the quality of the immune response. As a result, the immunological outcome stimulated by mannosylated substrates can vary substantially. Therefore, visualisation of the internalisation process and the corresponding localisation of the substrate within the cell are required in order to effectively map immune system response. Coupling a mannosylated substrate to an optical imaging agent provides a means of monitoring the uptake and traffic of the substrate. This principle has been partly explored using fluorescein-labeled mannosylated peptides for the targeted delivery of vaccines via the MR, though these compounds are yet to be applied in cellular imaging [10]. Overall, welldocumented expression and the capacity for specific uptake via a coordinated mannose moiety make the MR an excellent candidate for the targeting of lanthanide complexes, which are ideal for cellular imaging. This targeting could potentially be refined to specific organelles in the cell by utilising the controlled traffic of the human macrophage mannose receptor (MMR) (CD206) which, for example, employs specific endocytosis to transport soluble lysosomal enzymes into the endosome-lysosome system [11]. In addition, the MMR has also been isolated and purified allowing it to be used for in vitro receptor affinity investigations using conventional immunoassays (ELISA) and surface plasmon resonance (BIACORE). Thus, a stepwise approach can be employed after synthesis, from in vitro analysis to evaluation in live cells, which is ideal for probe development. Luminescent lanthanide complexes are resistant to photobleaching, allowing the extended periods of visualisation required to track the movements of a substrate in live cells. Free hydroxyl groups are known emission quenchers of lanthanide luminescence; thus, careful probe design will be required to avoid unwanted quenching derived from unprotected mannose hydroxyls. This work will focus firstly on the synthetic objective of coupling a mannose residue with affinity for the MR to a luminescent lanthanide chelate and secondly on investigating the effect of the mannose hydroxyls on emission intensity. Substrates with two or more mannose residues are known to show high affinity for the mannose receptor, particularly when linked in a branched formation [12,13]. For the purpose of this investigation, single $\alpha$-D-mannose residues and simple $\mathrm{Eu}(\mathrm{III})$ chelates were employed to avoid complicating the analysis of the mannose residue on emission intensity. In addition, a single mannose residue is expected to produce the same targeting effect as multiple mannose residues, though this effect will be slightly less pronounced.

\section{Materials and Methods}

The reagent $\alpha$-D-mannose pentaacetate was purchased from Chemsynlab (China); all other reagents and solvents were purchased from either Sigma-Aldrich or Merck and were used as received without any further purification unless otherwise specified. Although not strictly required, all reactions were performed under nitrogen atmosphere. Complexes 5 [14], $\mathbf{6}[15], \mathbf{1 1}[16]$, and $\mathbf{1 2}[17,18]$ were synthesised according to the literature procedures. For the investigation of photophysical properties, a dilute solution of the protonated complex (1-4) $\left(5 \times 10^{-5} \mathrm{M}\right)$ in water with constant ionic strength $(I=0.1 \mathrm{M}$ using $\mathrm{NaCl})$ was titrated against $\mathrm{NaOH}$. UVvisible absorption spectra were recorded using a Varian Cary UV-visible spectrophotometer over the range of 200-450 nm. Using excitation at $260 \mathrm{~nm}$, fluorescent measurements were recorded with a Cary Eclipse fluorimeter over the range of 300-550 nm and phosphorescent measurements over the range of $550-750 \mathrm{~nm}$.

2.1. 1,4,7,10-Tetraazacyclododecane-4,7,10-tri-t-butyl Acetate1-(N-(prop-2-yn-1-yl)) Acetamide (7). 5 (210 mg, $40.8 \mathrm{mmol})$, $\mathrm{Cs}_{2} \mathrm{CO}_{3}$ (265 mg, $81.6 \mathrm{mmol}$, 2eq), and $\mathrm{KI}$ (catalytic) were dissolved in $\mathrm{CH}_{3} \mathrm{CN}(30 \mathrm{~mL}) .6$ (72 mg, $40.8 \mathrm{mmol}$, leq) was added to the stirred mixture at room temperature under $\mathrm{N}_{2}$; then, the reaction was heated at $65^{\circ} \mathrm{C}$ overnight. The reaction was allowed to cool to room temperature and then filtered through a Celite pad in a sintered glass funnel. The filtrate was concentrated under reduced pressure to yield a solid yellow residue. The residue was redissolved in DCM $(20 \mathrm{~mL})$ forming a cloudy pale yellow solution. The organic layer was then washed with water $(3 \times 20 \mathrm{~mL})$ and $\mathrm{NaHCO}_{3}(3 \times 20 \mathrm{~mL})$ until the organic layer was transparent. The organic layer was then dried over $\mathrm{Na}_{2} \mathrm{SO}_{4}$ and filtered, and the solvent was removed under reduced pressure to yield an off-white, amorphous solid; $7(140 \mathrm{mg}, 56 \%) . \delta_{\mathrm{H}}\left(500 \mathrm{MHz}, \mathrm{CDCl}_{3}\right)$; $1.42\left(18 \mathrm{H}, \mathrm{s}, \mathrm{CH}_{3}\right), 1.43\left(9 \mathrm{H}, \mathrm{s}, \mathrm{CH}_{3}\right), 2.12(1 \mathrm{H}, \mathrm{t}, \mathrm{C} \equiv \mathrm{CH}$, 
$J=2.5 \mathrm{~Hz}), 2.49-2.88\left(16 \mathrm{H}, \mathrm{m}\right.$, cyclen- $\left.\mathrm{CH}_{2}\right), 3.07(2 \mathrm{H}, \mathrm{s}$, $\left.\mathrm{CH}_{2}\right), 3.24\left(4 \mathrm{H}, \mathrm{s}, \mathrm{CH}_{2}\right), 3.35\left(2 \mathrm{H}, \mathrm{s}, \mathrm{CH}_{2}\right), 4.01(2 \mathrm{H}, \mathrm{m}$, $\left.\mathrm{NHCH}_{2}\right) . \delta_{\mathrm{C}}\left(125 \mathrm{MHz}, \mathrm{CDCl}_{3}\right) ; 28.3\left(\mathrm{CH}_{3}\right), 28.7\left(\mathrm{C} \equiv \mathrm{CCH}_{2}\right)$, 52.2, 52.6, 53.8, $55.3\left(\right.$ cyclen- $\left.\mathrm{CH}_{2}\right), 56.4\left(\mathrm{COCH}_{2}\right), 56.6$ $\left(\mathrm{COCH}_{2}\right), 57.8\left(\mathrm{NHCOCH}_{2}\right), 70.3(\mathrm{C} \equiv \mathrm{CH}), 80.9(\mathbf{C} \equiv \mathrm{CH})$, 81.0, 81.2 $\left(\mathbf{C}\left(\mathrm{CH}_{3}\right)_{3}\right), 170.9,170.9(\mathbf{C}=\mathrm{O}), 172.2(\mathrm{NHC}=\mathrm{O})$. ESI/MS: $m / z=610.8\left(\mathrm{M}+\mathrm{H}^{+}\right), 632.8\left(\mathrm{M}+\mathrm{Na}^{+}\right), 306\left(\mathrm{M}^{++}\right)$.

2.2. $E$ Eu(III)-1,4,7,10-Tetraazacyclododecane-4,7,10-tri-t-butyl Acetate-1-(N-(prop-2-yn-1-yl)) Acetamide (8). $\mathrm{Eu}\left(\mathrm{CF}_{3} \mathrm{SO}_{3}\right)_{3}$ $\left(88 \mathrm{mg}, 1.48 \times 10^{-4} \mathrm{~mol}\right)$ was added to 7 (75 mg, $\left.1.23 \times 10^{-4} \mathrm{~mol}\right)$ in dry $\mathrm{MeOH}(10 \mathrm{~mL})$. The reaction was stirred at $65^{\circ} \mathrm{C}$ for $24 \mathrm{~h}$ under a $\mathrm{N}_{2}$ atmosphere. The solvent was then evaporated to leave a small volume $(<1 \mathrm{~mL})$ which was triturated with ether $(5 \mathrm{~mL})$. The resulting suspension was centrifuged and the supernatant was discarded. The white precipitate was then dried under high vacuum to yield a white powder; $8(78 \mathrm{mg}, 83 \%) . \delta_{\mathrm{H}}\left(300 \mathrm{MHz}, \mathrm{D}_{2} \mathrm{O}\right) ;-18.56$ (s), -17.25 (s), -15.84--15.38 (m), -13.97--13.33 (m), -12.41 (s), $-9.07(\mathrm{~s}),-7.93(\mathrm{~s}),-6.35(\mathrm{~s}),-4.48(\mathrm{~s}),-3.09(\mathrm{~s}),-0.32$ (s), $1.27(\mathrm{~m}), 2.53(\mathrm{~m}), 5.04(\mathrm{~m}), 30.23(\mathrm{~s}), 31.00(\mathrm{~s}), 31.55(\mathrm{~s})$, 32.55 (s). ESI-MS: $m / z=760\left(\mathrm{M}+\mathrm{H}^{+}\right)$.

2.3. 1,4,7,10-Tetraazacyclododecane-4,7,10-triacetic Acid-1-(N(prop-2-yn-1-yl)) Acetamide (9). Trifluoroacetic acid (3 mL) was added dropwise to a stirred solution of $7(100 \mathrm{mg}, 1.64 \times$ $\left.10^{-4} \mathrm{~mol}\right)$ in DCM $(3 \mathrm{~mL})$ and left to stir overnight at room temperature. The reaction mixture was then evaporated to produce a light brown syrup. The residue was redissolved in water $(10 \mathrm{~mL})$ and neutralised using $1 \mathrm{M} \mathrm{NaOH}$. The solvent was then evaporated to yield a white solid residue, which was redissolved in dry $\mathrm{MeOH}(2 \mathrm{~mL})$ and filtered through a $0.45 \mu \mathrm{m}$ nylon syringe filter. The filtrate was concentrated under reduced pressure and the process was repeated 2 times to yield a white powder; 9 (72 mg, quantitative). $\delta_{\mathrm{H}}$ $\left(300 \mathrm{MHz}, \mathrm{CDCl}_{3}\right) ; 2.60(1 \mathrm{H}, \mathrm{s}, \mathrm{C} \equiv \mathrm{CH}), 3.08-3.25(8 \mathrm{H}, \mathrm{m}$, cyclen- $\left.\mathrm{CH}_{2}\right), 3.38-3.60\left(12 \mathrm{H}, \mathrm{m}\right.$, cyclen- $\left.\mathrm{CH}_{2}\right), 3.80(6 \mathrm{H}, \mathrm{m}$, $\left.\mathrm{CH}_{2}\right), 3.98\left(2 \mathrm{H}, \mathrm{m}, \mathrm{CH}_{2} \mathrm{CONH}\right), 4.01\left(2 \mathrm{H}, \mathrm{m}, \mathrm{NHCH}_{2}\right) ; \delta_{\mathrm{C}}$ (75 MHz, $\left.\mathrm{D}_{2} \mathrm{O}\right) ; 180.0,179.8(\mathrm{CO}), 170.6(\mathrm{CO}), 80.7(\underline{\mathrm{C}} \equiv \mathrm{CH})$, $72.6(\mathrm{C} \equiv \underline{\mathrm{CH}}), 58.2,57.9\left(\mathrm{NCH}_{2} \mathrm{CO}\right), 57.2\left(\mathrm{NCH}_{2} \mathrm{CO}\right), 53.1$, 52.4, 49.8, $49.0\left(\mathrm{CH}_{2}\right.$-cyclen $), 27.5\left(\mathrm{NHCH}_{2}\right)$. ESI/MS: 442.4 $\left(\mathrm{M}+\mathrm{H}^{+}\right), 464.5\left(\mathrm{M}+\mathrm{Na}^{+}\right)$.

2.4. $\quad \mathrm{Eu}(\mathrm{III})-1,4,7,10$-Tetraazacyclododecane-4,7,10-triacetic Acid-1-(N-(prop-2-yn-1-yl)) Acetamide (10). $\mathrm{Eu}\left(\mathrm{CF}_{3} \mathrm{SO}_{3}\right)_{3}$ $\left(335 \mathrm{mg}, \quad 5.59 \times 10^{-4} \mathrm{~mol}\right)$ was added to 9 (247 mg, $\left.5.59 \times 10^{-4} \mathrm{~mol}\right)$ in dry $\mathrm{MeOH}(10 \mathrm{~mL})$. The reaction was stirred at $65^{\circ} \mathrm{C}$ for $24 \mathrm{~h}$ under a $\mathrm{N}_{2}$ atmosphere. The suspension was then centrifuged and the supernatant was discarded, leaving a white solid. The white solid was dried further under high vacuum to yield a white powder; 10 (200 mg, 60\%). $\delta_{\mathrm{H}}\left(500 \mathrm{MHz}, \mathrm{D}_{2} \mathrm{O}\right) ;-16.77(\mathrm{~s}),-15.76(\mathrm{~s})$, $-14.91(\mathrm{~s}),-14.61--14.62(\mathrm{~m}),-12.39(\mathrm{~s}),-11.71(\mathrm{~s}),-11.05(\mathrm{~s})$, $-8.13(\mathrm{~s}),-7.76(\mathrm{~s}),-7.19(\mathrm{~s}),-5.71(\mathrm{~s}),-4.32(\mathrm{~s}),-3.45(\mathrm{~s})$, -2.45 (s), -0.40 (s), 0.00 (s), 3.50 (s), 4.05 (s), 30.41 (s), 30.72 (s), 31.63 (s), 33.01 (s). ESI-MS: $m / z=592\left(\mathrm{M}+\mathrm{H}^{+}\right)$.

1: To a stirred solution of $\mathbf{8}\left(23 \mathrm{mg}, 3.02 \times 10^{-5} \mathrm{~mol}\right)$ and 11 (11 mg, $\left.3.93 \times 10^{-5} \mathrm{~mol}\right)$ in $\mathrm{DMF} / \mathrm{H}_{2} \mathrm{O}(5: 1)(4 \mathrm{~mL})$ under
$\mathrm{N}_{2}$ were added sodium ascorbate $\left(3 \mathrm{mg}, 1.21 \times 10^{-5} \mathrm{~mol}\right)$ in $\mathrm{DMF} / \mathrm{H}_{2} \mathrm{O}(5: 1)(0.5 \mathrm{~mL})$ and copper sulphate pentahydrate $\left(2 \mathrm{mg}, 6.04 \times 10^{-6} \mathrm{~mol}\right)$ in $\mathrm{DMF} / \mathrm{H}_{2} \mathrm{O}(5: 1)(0.5 \mathrm{~mL})$. The reaction was allowed to stir for $24 \mathrm{~h}$ at room temperature. The solvent was then evaporated and the residue was redissolved in $\mathrm{H}_{2} \mathrm{O}(1 \mathrm{~mL})$, filtered through $0.45 \mu \mathrm{m}$ nylon, and purified using Sephadex G-10 column chromatography in $\mathrm{H}_{2} \mathrm{O}$ to yield a white powder; $1(26 \mathrm{mg}, 85 \%) . \delta_{\mathrm{H}}\left(300 \mathrm{MHz}, \mathrm{D}_{2} \mathrm{O}\right)$; $-18.28--16.82(\mathrm{~m}),-13.67(\mathrm{~s}),-12.64(\mathrm{~s}),-11.21(\mathrm{~s}),-6.63(\mathrm{~s})$, $-4.62(\mathrm{~s}),-3.75(\mathrm{~s}),-2.59(\mathrm{~s}),-1.67(\mathrm{~s}),-1.19(\mathrm{~s}), 0.20$ (s), 1.51$5.28(\mathrm{~m}), 8.31(\mathrm{~s}), 9.04(\mathrm{~s}), 9.61(\mathrm{~s}), 33.89$ (s), 34.59 (s), 35.70 (s), 38.05 (s). ESI-MS: $m / z=1012\left(\mathrm{M}+\mathrm{H}^{+}\right)$. Calculated for $\mathrm{C}_{39} \mathrm{H}_{72} \mathrm{~N}_{8} \mathrm{O}_{14} \mathrm{Eu}: \mathrm{C}, 45.42 ; \mathrm{H}, 7.05 ; \mathrm{N}, 10.89$; Found: C, 45.24; $\mathrm{H}, 6.89 ; \mathrm{N}, 10.81$.

2: To a stirred solution of $\mathbf{8}\left(23 \mathrm{mg}, 3.02 \times 10^{-5} \mathrm{~mol}\right)$ and 12 (16 mg, $\left.3.93 \times 10^{-5} \mathrm{~mol}\right)$ in $\mathrm{DMF} / \mathrm{H}_{2} \mathrm{O}(5: 1)(4 \mathrm{~mL})$ under $\mathrm{N}_{2}$ were added sodium ascorbate $\left(3 \mathrm{mg}, 1.21 \times 10^{-5} \mathrm{~mol}\right)$ in $\mathrm{DMF} / \mathrm{H}_{2} \mathrm{O}(5: 1)(0.5 \mathrm{~mL})$ and copper sulphate pentahydrate $\left(2 \mathrm{mg}, 6.04 \times 10^{-6} \mathrm{~mol}\right)$ in $\mathrm{DMF} / \mathrm{H}_{2} \mathrm{O}(5: 1)(0.5 \mathrm{~mL})$. The reaction was allowed to stir for $24 \mathrm{~h}$ at room temperature. The solvent was then evaporated and the residue redissolved in $\mathrm{H}_{2} \mathrm{O}(1 \mathrm{~mL})$, filtered through $0.45 \mu \mathrm{m}$ nylon, and purified using sephadex G-10 column chromatography in $\mathrm{H}_{2} \mathrm{O}$ to yield a white powder; $2(27 \mathrm{mg}, 75 \%) . \delta_{\mathrm{H}}\left(300 \mathrm{MHz}, \mathrm{D}_{2} \mathrm{O}\right)$; $-18.44(\mathrm{~s}),-17.01(\mathrm{~m}),-13.95(\mathrm{~m}),-12.07(\mathrm{~m}),-6.86--6.59$ (m), -3.92 (m), -2.99 (m), -2.15 (m), -1.24 (s), -0.21 (s), 0.19$5.30(\mathrm{~m}), 8.18(\mathrm{~m}), 33.48(\mathrm{~s}), 33.52(\mathrm{~s}), 34.67(\mathrm{~s}), 37.09(\mathrm{~s})$. ESIMS: $m / z=1180\left(\mathrm{M}+\mathrm{H}^{+}\right)$. Calculated for $\mathrm{C}_{47} \mathrm{H}_{80} \mathrm{~N}_{8} \mathrm{O}_{18} \mathrm{Eu}$ : C, 47.15; H, 6.74; N, 9.36; Found: C, 47.02; H, 6.88; N, 9.21.

3: To a stirred solution of $\mathbf{1 0}\left(27 \mathrm{mg}, 4.55 \times 10^{-5} \mathrm{~mol}\right)$ and 11 (17 mg, $\left.6.83 \times 10^{-5} \mathrm{~mol}\right)$ in $\mathrm{DMF} / \mathrm{H}_{2} \mathrm{O}(5: 1)(4 \mathrm{~mL})$ under $\mathrm{N}_{2}$ were added sodium ascorbate $\left(4 \mathrm{mg}, 1.82 \times 10^{-5} \mathrm{~mol}\right)$ in $\mathrm{DMF} / \mathrm{H}_{2} \mathrm{O}(5: 1)(0.5 \mathrm{~mL})$ and copper sulphate pentahydrate $\left(2 \mathrm{mg}, 9.11 \times 10^{-6} \mathrm{~mol}\right)$ in $\mathrm{DMF} / \mathrm{H}_{2} \mathrm{O}(5: 1)(0.5 \mathrm{~mL})$. The reaction was allowed to stir for $24 \mathrm{~h}$ at room temperature. The solvent was then evaporated and the residue redissolved in $\mathrm{H}_{2} \mathrm{O}(1 \mathrm{~mL})$, filtered through $0.45 \mu \mathrm{m}$ nylon, and purified using sephadex G-10 column chromatography in $\mathrm{H}_{2} \mathrm{O}$ to yield a white powder; $3(7 \mathrm{mg}, 18 \%) . \delta_{\mathrm{H}}\left(300 \mathrm{MHz}, \mathrm{D}_{2} \mathrm{O}\right)$ $-16.52(\mathrm{~s}),-15.54(\mathrm{~s}),-14.85--14.22(\mathrm{~m}),-12.35(\mathrm{~s}),-11.78$ (s), -11.19 (s), $-10.76(\mathrm{~s}),-7.88(\mathrm{~s}),-7.45(\mathrm{~s}),-7.02(\mathrm{~s}),-5.76$ $(\mathrm{s}),-4.31(\mathrm{~s}),-3.13(\mathrm{~s}),-2.78(\mathrm{~s}),-2.33(\mathrm{~s}),-2.11(\mathrm{~s}),-0.23-$ $-0.07(\mathrm{~m}), 2.72(\mathrm{~m}), 3.61(\mathrm{~m}), 8.64(\mathrm{~m}), 10.28(\mathrm{~s}), 30.74(\mathrm{~s})$, 30.95 (s), 31.66 (s), 32.95 (s). ESI-MS: $m / z=840\left(\mathrm{M}+\mathrm{H}^{+}\right)$. Calculated for $\mathrm{C}_{27} \mathrm{H}_{45} \mathrm{~N}_{8} \mathrm{O}_{14} \mathrm{Eu}$ : C, 37.81; H, 5.29; N, 13.07; Found: C, 37.64; H, 5.36; N, 13.00.

4: To a stirred solution of $\mathbf{1 0}\left(20 \mathrm{mg}, 3.37 \times 10^{-5} \mathrm{~mol}\right)$ and 12 (15 mg, $\left.3.71 \times 10^{-5} \mathrm{~mol}\right)$ in $\mathrm{DMF} / \mathrm{H}_{2} \mathrm{O}(5: 1)(4 \mathrm{~mL})$ under $\mathrm{N}_{2}$ were added sodium ascorbate $\left(3 \mathrm{mg}, 1.35 \times 10^{-5} \mathrm{~mol}\right)$ in $\mathrm{DMF} / \mathrm{H}_{2} \mathrm{O}(5: 1)(0.5 \mathrm{~mL})$ and copper sulphate pentahydrate $\left(2 \mathrm{mg}, 6.75 \times 10^{-6} \mathrm{~mol}\right)$ in $\mathrm{DMF} / \mathrm{H}_{2} \mathrm{O}(5: 1)(0.5 \mathrm{~mL})$. The reaction was allowed to stir for $24 \mathrm{~h}$ at room temperature. The solvent was then evaporated and the residue redissolved in $\mathrm{H}_{2} \mathrm{O}(1 \mathrm{~mL})$, filtered through $0.45 \mu \mathrm{m}$ nylon, and purified using sephadex G-10 column chromatography in $\mathrm{H}_{2} \mathrm{O}$ to yield a white powder; $4(12 \mathrm{mg}, 35 \%) . \delta_{\mathrm{H}}\left(300 \mathrm{MHz}, \mathrm{D}_{2} \mathrm{O}\right)$; -16.87 (s), -15.88 (s), -15.19--14.53 (m), -12.42 (s), -11.94 (s), $-11.52(\mathrm{~s}),-11.12(\mathrm{~s}),-7.95(\mathrm{~s}),-7.43(\mathrm{~s}),-7.06$ (s), 

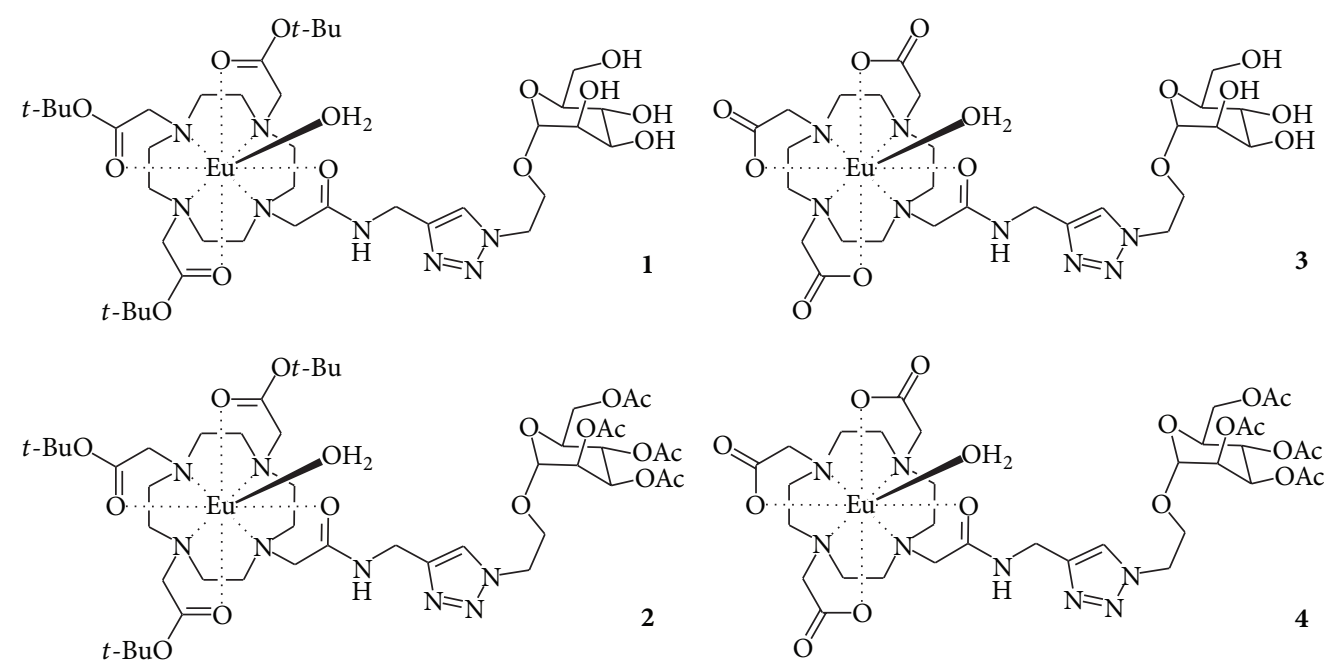

FIGURE 1: Structures of the targeted luminescent lanthanide complexes synthesised in this study.

$-5.83(\mathrm{~s}),-4.50(\mathrm{~s}),-3.13--2.89(\mathrm{~m}),-2.46(\mathrm{~s}),-0.08(\mathrm{~s})$, $2.20(\mathrm{~m}), 3.31(\mathrm{~m}), 8.18(\mathrm{~s}), 10.28(\mathrm{~s}), 31.20(\mathrm{~s}), 31.40(\mathrm{~s}), 31.97$ (s), 33.34 (s). ESI-MS: $m / z=1008\left(\mathrm{M}+\mathrm{H}^{+}\right)$. Calculated for $\mathrm{C}_{35} \mathrm{H}_{53} \mathrm{~N}_{8} \mathrm{O}_{18} \mathrm{Eu}: \mathrm{C}, 40.98 ; \mathrm{H}, 5.21 ; \mathrm{N}, 10.92$; Found: C, 40.99; $\mathrm{H}, 5.37 ; \mathrm{N}, 10.77$.

\section{Results and Discussion}

The complexes in this study (Figure 1) were designed with either free mannose hydroxyls or acetyl protecting groups to compare their corresponding emission intensities and determine the extent of any hydroxyl quenching. Q-values were calculated for each complex to provide insight into the binding of mannose hydroxyls at the lanthanide center, which would result in the displacement of metal bound waters. Complexes with carboxylic acid pendant arms were compared to those with $t$-butyl pendant arms to elucidate any synergistic or additional quenching effects that may be of consequence for future probe design. Carboxylic acid pendant arms are expected to quench the lanthanide emission to a small degree due to hydroxyl quenching, though their inherent water solubility is an advantageous property for a cellular imaging agent. In contrast, a complex with small hydrophobic pendant arms, higher emission, and similar water solubility would be more beneficial for cellular applications. Emission quenching at low $\mathrm{pH}$ is a concern for live cell imaging, particularly in the endosome-lysosome system where $\mathrm{pH}$ can drop below $\mathrm{pH} 4$ after internalisation. Thus, $\mathrm{pH}$ titrations were performed on each complex to determine their functionality at low $\mathrm{pH}$. Analysing all of these factors using a quick initial synthesis will provide a solid platform for the synthesis of new, targeted cellular imaging agents. Herein, the synthesis and characterisation of a first generation of $\mathrm{Eu}(\mathrm{III})$ complexes as targeted optical probes will be discussed. The information gained from the synthesis and investigation of the photophysical properties of the probes will then be employed in the design of a second generation of targeted lanthanide probes.
Complexes $\mathbf{1}$ and $\mathbf{2}$ were synthesised in a similar fashion following Figure 2: Scheme 1. The synthesis of both $\mathbf{1}$ and $\mathbf{2}$ began with the alkylation of 1,4,7,10-tetraazacyclododecane (cyclen) at the N-1, 4 and 7 positions using $t$-butyl bromoacetate in the presence of sodium acetate trihydrate in dimethylformamide (DMF). Selective crystallisation yielded a trisubstituted bromide salt (5) in 34\% yield. The remaining cyclen amine was then further alkylated with an alkyne functionalised pendant arm (6) using 2 equivalents of cesium carbonate in acetonitrile with a few crystals of potassium iodide as a catalyst. Following filtration the tetrasubstituted product (7) was isolated as a white solid in 95\% yield. Europium complexation was then performed prior to the 1,3-dipolar cycloaddition reaction ("click" reaction) to ensure no copper was taken up by the macrocycle, which would have inhibited europium binding. Europium complexation was achieved by refluxing the ligand with 1 equivalent of europium triflate in dry methanol $(\mathrm{MeOH})$. The resulting complex (8) was then isolated by trituration with diethyl ether to yield a white powder in $90 \%$ yield. The europium complex (8) was then reacted with either an unprotected (11) or protected (12) azido-mannose residue in the presence of a copper catalyst $\left(\mathrm{CuSO}_{4} \cdot 5 \mathrm{H}_{2} \mathrm{O}\right)$ and a reducing agent (sodium ascorbate) to produce complexes 1 and 2, respectively. A partially aqueous solvent system of $\mathrm{DMF} / \mathrm{H}_{2} \mathrm{O}(8: 2)$ was used to ensure all reactants were soluble in the reaction mixture. An excess of azido-mannose residue was used in each reaction to ensure the reaction went to completion. Following evaporation of the mixed reaction solvent, purification of each product from sodium ascorbate, residual copper, and excess azido-mannose was achieved using column chromatography with Sephadex G-10 size exclusion media in Milli-Q water. The solvent was then removed through evaporation and the corresponding residue was dried under high vacuum to produce complexes 1 and $\mathbf{2}$ in $85 \%$ and $75 \%$ yield, respectively. The synthesis of $\mathbf{3}$ and $\mathbf{4}$ (Figure 2: Scheme 1) proceeded via the same steps as the synthesis of complexes $\mathbf{1}$ and $\mathbf{2}$, though instead of complexing 7 directly, the three $t$-butyl pendant arms of compound 7 were hydrolysed to carboxylic acids 


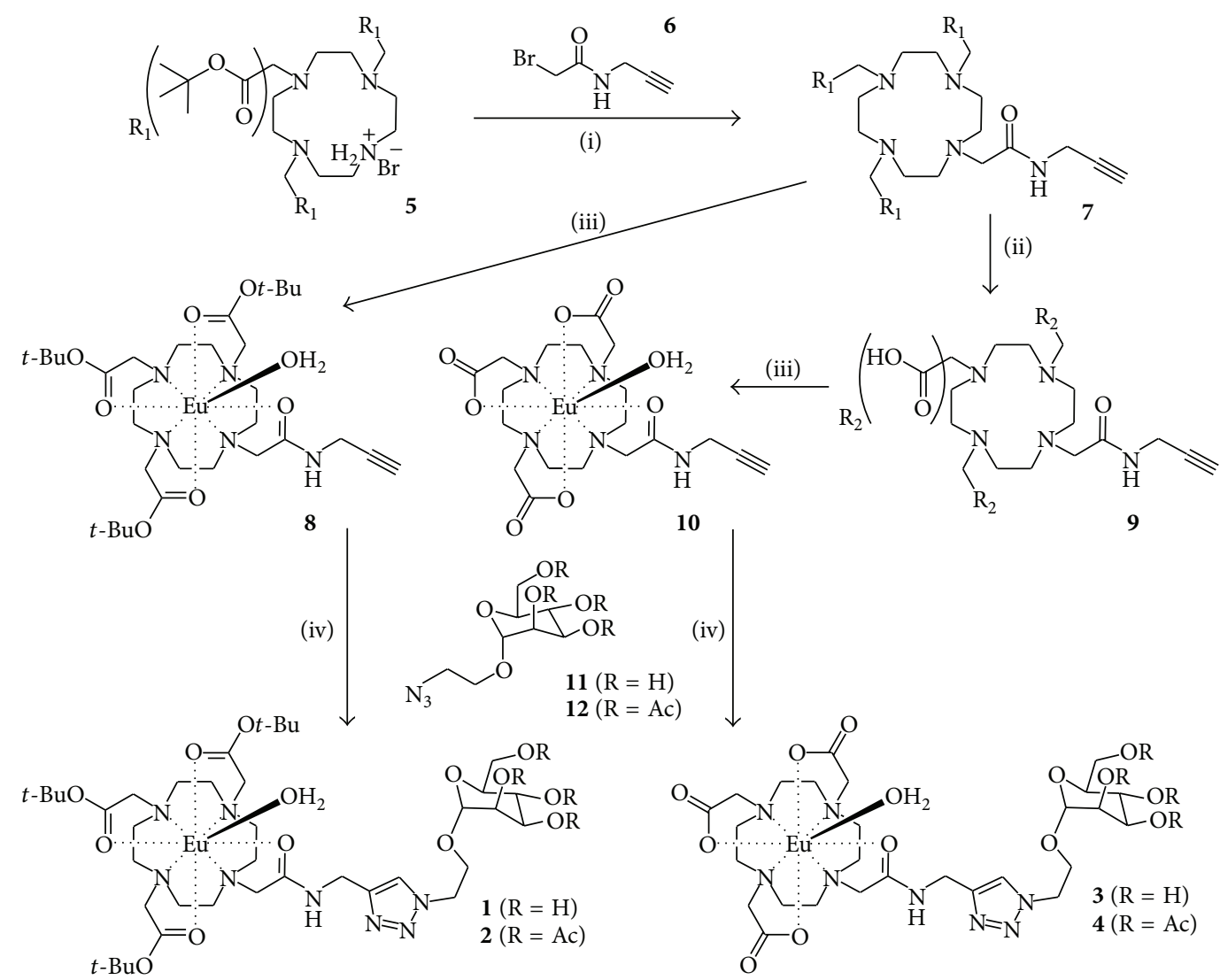

FIGURE 2: Scheme 1: synthetic pathway for the synthesis of complexes 1-4. Reagents and conditions: (i) $\mathrm{Cs}_{2} \mathrm{CO}_{3}, \mathrm{CH}_{3} \mathrm{CN}, 65^{\circ} \mathrm{C}, 24 \mathrm{~h}$; (ii) $\mathrm{TFA}$, $\operatorname{DCM}(1: 1), \mathrm{RT}, 24 \mathrm{~h}$; (iii) $\mathrm{Eu}\left(\mathrm{CF}_{3} \mathrm{SO}_{3}\right)_{3}, \mathrm{MeOH}, 65^{\circ} \mathrm{C}, 24 \mathrm{~h}$; (iv) $\mathrm{CuSO}_{4} \cdot 5 \mathrm{H}_{2} \mathrm{O}$, sodium ascorbate, DMF/ $\mathrm{H}_{2} \mathrm{O}(8: 2)$.

using TFA/dichloromethane $(1: 1)$ to form the free ligand 9 in quantitative yield. Europium complexation of 9 was then performed by refluxing the ligand with 1.1 equivalents of europium triflate in dry $\mathrm{MeOH}$. Complexation resulted in the formation of an insoluble complex as a white precipitate. Due to the difference in solubility between the ligand and the complex, an excess of europium triflate was employed to ensure a quantitative yield. The europium complex (10) was isolated from the reaction mixture through a simple filtration to yield the complex as a white powder in quantitative yield. This complex (10) was then reacted with either an unprotected (11) or protected (12) azido-mannose residue in the presence of $\mathrm{CuSO}_{4} \cdot 5 \mathrm{H}_{2} \mathrm{O}$ and sodium ascorbate in DMF/ $\mathrm{H}_{2} \mathrm{O}(8: 2)$ to produce complexes 3 and 4 respectively. The yields for 3 and $4,18 \%$ and 35\%, respectively, were lower than those generated for $\mathbf{1}$ and $\mathbf{2}$, which may be attributable to interaction of the carboxylic acid pendant arms with the copper catalyst.

The NMR spectra of complexes $\mathbf{1 - 4}$, as shown in Supplementary Figures 1-4 in Supplementary Material available online at http://dx.doi.org/10.1155/2013/498598, respectively, are consistent with those observed for unsymmetrically substituted cyclen derivatives, in which all the protons are nonequivalent. For each complex 16-25 resonances were observed outside the range between 0 and $10 \mathrm{ppm}$. The four most shifted resonances in the downfield part of the spectrum $(30-40 \mathrm{ppm})$ are assigned to axial ring protons on the cyclen ring. These four resonances are present in complexes 1-4 and were assigned to the signals of a single square antiprismatic (SAP) isomer $[19,20]$. In the spectra of complexes 3 and 4 , there is a small broad resonance at $10.4 \mathrm{ppm}$. This is the only resonance in the range of $10-25 \mathrm{ppm}$, indicating that there was no twisted square antiprismatic isomer observed for any of the complexes. The spectra for complexes 1-4 all show sharp and relatively narrow resonances implying that the barriers to arm rotation for each complex are sufficient to prevent a ready exchange between diastereomers in solution.

To observe the influence of the mannose residue on the $\mathrm{Eu}(\mathrm{III})$ emission, the photophysical properties of complexes 1-4 were recorded as a function of $\mathrm{pH}$. The UV-visible absorption spectrums of complexes 1-4 (Supplementary Figure 5) all displayed a strong absorption band below $260 \mathrm{~nm}$ with a shoulder centred around $275 \mathrm{~nm}$. The band below $260 \mathrm{~nm}$ is attributed to the $\pi-\pi^{*}$ transition of the triazole moiety, whilst the shoulder centred around $275 \mathrm{~nm}$ corresponds to LMCT from the 1,2,3-triazole linker to the $\mathrm{Eu}(\mathrm{III})$ metal ion [15]. All complexes exhibited an increase in the absorption of the band below $260 \mathrm{~nm}$ with increasing $\mathrm{pH}$. The shoulder at $275 \mathrm{~nm}$ was found to be relatively $\mathrm{pH}$ insensitive, except in complex 4 where a slight decrease in absorption was recorded with increasing $\mathrm{pH}$.

After excitation at $260 \mathrm{~nm}$, emission from the singlet state of the triazole moiety in each complex was observed as a function of $\mathrm{pH}$ (complex 4 represented in Figure 3(a)). 


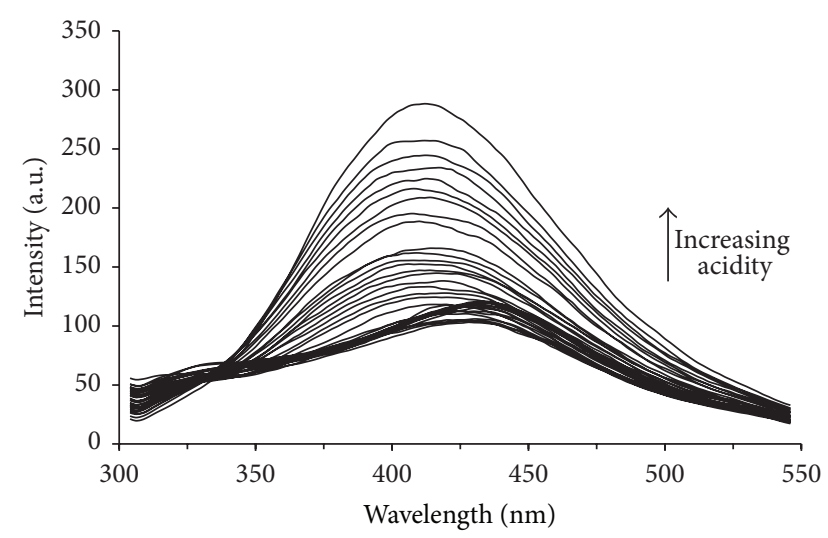

(a)

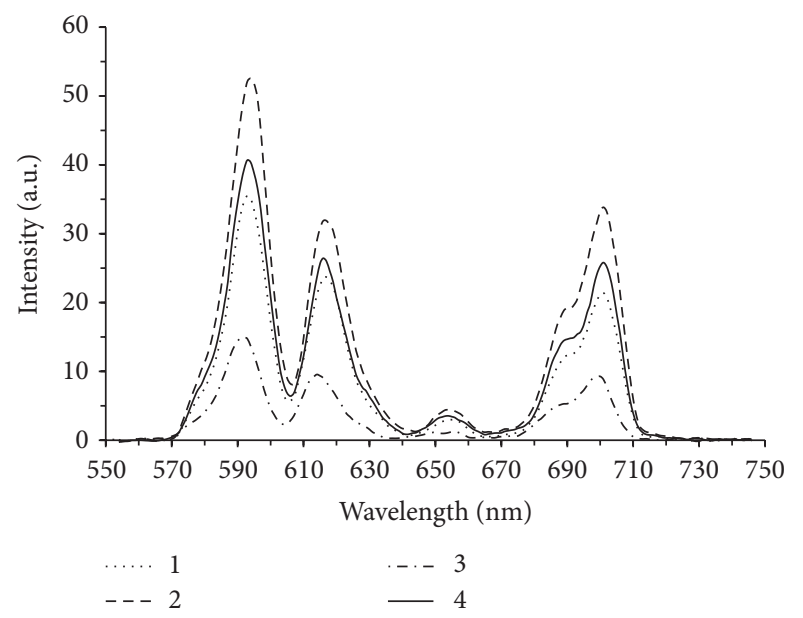

(b)

FIGURE 3: Complex 4: fluorescence spectra-260 nm excitation (a), phosphorescence spectra of complexes 1-4 at $\mathrm{pH} 7.10-260 \mathrm{~nm}$ excitation (b).

The fluorescent spectra of all four complexes (Supplementary Figure 6) showed two emission maxima between 350 and $450 \mathrm{~nm}$ that were found to vary with $\mathrm{pH}$. Examination of the change in fluorescent emission with response to $\mathrm{pH}$ revealed that each complex had $2 \mathrm{p} K_{\mathrm{a}}$ values at approximately $\mathrm{pH} 4.2$ and 7.5 .

Phosphorescent spectra were recorded using indirect excitation via the triazole moiety, as opposed to direct excitation at $395 \mathrm{~nm}$ (complex 4 represented in Figure 3(b)) (complexes 1-4 represented in Supplementary Figure 7). The triplet state of the 1,2,3-triazole linker in each of the complexes was capable of transferring energy to the triplet state of the $\mathrm{Eu}(\mathrm{III})$ ion via an antenna effect. It is important to note here that, since the triplet state energy of the 1,2,3-triazole linker is less than $2000 \mathrm{~cm}^{-1}$ above the first excited state of the $\mathrm{Eu}(\mathrm{III})$ ion $\left({ }^{5} \mathrm{D}_{0}-17,200 \mathrm{~cm}^{-1}\right)$, the efficiency of the energy transfer is significantly decreased via back transfer of energy to the triplet state of the 1,2,3-triazole linker. Linelike emission bands characteristic of $\mathrm{Eu}(\mathrm{III})$ emission from ${ }^{5} \mathrm{D}_{0} \rightarrow{ }^{7} \mathrm{~F}_{J}$ (where $J=0-4$ ) were observed for all complexes. $J$-bands $0,1,2$, and 3 were observed at 577 (shoulder), 592, 615 , and $654 \mathrm{~nm}$, respectively, whilst $J$-band 4 was observed at $700 \mathrm{~nm}$ with a shoulder at $689 \mathrm{~nm}$ [21-24]. The ${ }^{5} \mathrm{D}_{0} \rightarrow{ }^{7} \mathrm{~F}_{5}$ and ${ }^{5} \mathrm{D}_{0} \rightarrow{ }^{7} \mathrm{~F}_{6}$ emission bands were not observed for any of the complexes.

The phosphorescent intensities of $\mathbf{1}$ and $\mathbf{2}(t$-Bu pendant arms) using $260 \mathrm{~nm}$ excitation wavelength were enhanced in comparison to 3 and 4 (COOH pendant arms), respectively. This demonstrated that carboxylic acid pendant arms have a quenching effect on the phosphorescent emission of Eu(III) compared with the $t$-butyl pendant arms. This quenching effect is expected, as oscillations from $\mathrm{O}-\mathrm{H}$ bonds are known quenchers of Eu(III) triplet states. However, there was a small decrease in water solubility observed for complexes with hydrophobic pendant arms but this was outweighed by a concomitant increase in emission intensity, suggesting that small hydrophobic pendant arms are the most desirable for optical probe design.

The phosphorescent intensities of $\mathbf{2}$ and $\mathbf{4}$ (acetylated mannose) at $592 \mathrm{~nm}$ were enhanced in comparison to 1 and $\mathbf{3}$ (unprotected mannose), respectively. This demonstrated that the hydroxyl groups of the unprotected mannose residues produced a quenching effect on the phosphorescent emission from $\mathrm{Eu}(\mathrm{III})$. Under identical conditions, complex 2 produced the highest emission intensity as a result of $t$ - $\mathrm{Bu}$ pendant arms and protected mannose hydroxyls and complex 3 produced the lowest emission with carboxylic acid pendant arms and free mannose hydroxyls.

The phosphorescent emission from complexes 1-4 was relatively $\mathrm{pH}$ insensitive, though small scale changes were observed and can be attributed to either variation in the electronic structure of the antenna or the coordination environment of the lanthanide ion. The steady emission in complexes 1-4 over the $\mathrm{pH}$ range 6-8 suggests that altering the coordination environment of the lanthanide (e.g., metal bound waters) does not significantly affect the phosphorescence emission for these complexes. However, a comparison of fluorescence and phosphorescent emission at different $\mathrm{pH}$ for each of the complexes showed that emission intensity varied over the same $\mathrm{pH}$ ranges, though the effects are significantly masked in the phosphorescence spectra. This suggests that the small scale differences observed in the phosphorescent emission may be attributed to fluctuations in the antenna's electronic environment, as opposed to changes in the inner-shell coordination environment of the lanthanide ion.

In order to ascribe these effects, $\mathrm{p} K_{\mathrm{a}}$ values of compounds with similar structural features were compared to the $\mathrm{p} K_{\mathrm{a}}$ 's observed from the absorption and emission spectra of each complex. The $\mathrm{p} K_{\mathrm{a}}$ of the triazole linker is approximately 1.2; hence, protonation/deprotonation at this site is unlikely to affect the emission of complexes 1-4 over the $\mathrm{pH}$ range of $2-10$. It is also improbable that the coordinated $\alpha$-Dmannose residue is responsible for the changes observed in the fluorescent spectra of each complex, as the $\mathrm{p} K_{\mathrm{a}}$ of $\alpha$-Dmannose is 12.08. Therefore, as all of the complexes show evidence of a $\mathrm{p} K_{\mathrm{a}}$ at 7.5 in their fluorescence spectra, but not in the phosphorescent spectra, it is likely that delocalisation centred around the amide bond [25] affects the $\pi \pi^{*}$ band observed at $260 \mathrm{~nm}$ in their UV-visible spectra. This effect appears to influence the singlet state of the triazole to a greater extent than the triplet state, resulting in a change 
TABLE 1: Lifetime measurements for complexes $\mathbf{1}-\mathbf{4}^{\mathrm{a}}$.

\begin{tabular}{lcccc}
\hline Complex & $\mathrm{pH}$ & $\tau_{\mathrm{H}_{2} \mathrm{O}} / \mathrm{ms}$ & $\tau_{\mathrm{D}_{2} \mathrm{O}} / \mathrm{ms}$ & $Q$-value \\
\hline $\mathbf{1}$ & 6.8 & 0.571 & 1.462 & $\mathbf{0 . 8 4}$ \\
$\mathbf{2}$ & 6.6 & 0.589 & 1.804 & $\mathbf{0 . 9 4}$ \\
$\mathbf{3}$ & 6.8 & 0.603 & 2.091 & $\mathbf{0 . 9 7}$ \\
$\mathbf{4}$ & 6.8 & 0.593 & 2.038 & $\mathbf{0 . 9 9}$ \\
\hline
\end{tabular}

${ }^{\mathrm{a}}$ Luminescent lifetimes of complexes 1-4 in $\mathrm{H}_{2} \mathrm{O}$ and $\mathrm{D}_{2} \mathrm{O}$ at neutral $\mathrm{pH}$ and corresponding metal bound water calculations ( $q$-value).

in the fluorescent emission whilst the phosphorescence (via energy transfer from the triplet state of the triazole) remains unaffected. This is also supported by the observation of a slight bathochromic shift for each of the fluorescent emission bands, as a bathochromic shift indicates an increase in electron delocalisation. The effect of the $\mathrm{p} K_{\mathrm{a}}$ at 4.2 was observed in the fluorescence spectra of all complexes, though the effect was not significant in any of the phosphorescence spectra. This suggests that the effect is derived from a source which is distant from the $\mathrm{Eu}(\mathrm{III})$ centre, potentially the attached mannose residue. Luminescent lifetimes were then calculated at different $\mathrm{pH}$ to confirm these observations.

The luminescent lifetimes of complexes 1-4 at neutral $\mathrm{pH}$ are reported in Table 1 . In all cases, indirect excitation was employed using the LMCT band at $260 \mathrm{~nm}$ and the lifetime of the phosphorescent emission was recorded from the $J=1$ band of the Eu(III) emission at $592 \mathrm{~nm}$ (see Supplementary Table 1 for fluorimeter settings). Table 1 shows the calculated values of $q$, the number of bound solvent oscillators, using the following equation:

$$
q=A_{\mathrm{Ln}}\left[\left(\frac{1}{\tau_{\mathrm{H}_{2} \mathrm{O}}}\right)-\left(\frac{1}{\tau_{\mathrm{D}_{2} \mathrm{O}}}\right)-B_{\mathrm{Ln}}\right]
$$

where $\tau_{\mathrm{H}_{2} \mathrm{O}}$ and $\tau_{\mathrm{D}_{2} \mathrm{O}}$ are the lifetimes observed in $\mathrm{H}_{2} \mathrm{O}$ and $\mathrm{D}_{2} \mathrm{O}$, respectively, and $A_{\mathrm{Ln}}$ and $B_{\mathrm{Ln}}$ are constants for a given lanthanide and solvent system: in water; $A_{\mathrm{Eu}}=1.2 \mathrm{~ms}, B_{\mathrm{Eu}}=$ $(0.25+0.075 x) \mathrm{ms}^{-1}$, and $x$ is the number of exchangeable amide $\mathrm{NH}$ oscillators in the ligand coordination sphere (1 in the case of complexes 1-4). Changing the $\mathrm{pH}$ of the solution had no effect on the calculated $q$-values for each of the complexes, all of which demonstrated a $q$-value of $<1$ at all values of $\mathrm{pH}$ (see Supplementary Table 2). These results confirm the lack of $\mathrm{pH}$ sensitivity observed in the phosphorescent emission spectra and support the conclusions that fluorescence emission was influenced by a change in the electronic structure of the amide bond $\left(\mathrm{p} K_{\mathrm{a}}=7.5\right)$ and the effect relating to the $\mathrm{p} K_{\mathrm{a}}$ at 4.2 resulted from a structural change distant from the $\mathrm{Eu}$ (III) centre. Furthermore, the lack of $\mathrm{pH}$ sensitivity in the $q$-values of complexes $\mathbf{1 - 4}$ shows that the mannose hydroxyls do not participate in binding at the $\mathrm{Eu}$ (III) centre. Therefore, the observed quenching effects do not appear to be a direct result of $\mathrm{OH}$ oscillations from the coordinated mannose residue.

\section{Conclusions}

The phosphorescence emission from each of the complexes appeared to be relatively insensitive to $\mathrm{pH}$. The $\mathrm{pH}$ insensitivity of the probes, in particular the lack of quenching at low $\mathrm{pH}$, is ideal for use in the endosome-lysosome system where the $\mathrm{pH}$ can reach as low as $\mathrm{pH} 4$. Analysis of the phosphorescent emission data revealed that the coordinated mannose residue had a pronounced effect on emission intensity. Free mannose hydroxyls quenched the emission significantly, whilst the carboxylic acid pendant arms quenched the emission only to a small degree. While it is known that hydroxyl groups quench lanthanide emission, it was not expected that the hydroxyl groups on the mannose residue would have such a pronounced effect since they are at some distance from the chelate and are not involved in binding at the chelate. Taken together, this suggests that the mannose hydroxyls are not directly influencing lanthanide emission but are instead interacting with water molecules in the second hydration sphere to create a quenching effect at the $\mathrm{Eu}(\mathrm{III})$ centre $[26,27]$. This is an important observation, as this quenching effect is expected to be more profound with the incorporation of multiple mannose residues into the probe structure. With regard to the next generation of probes, this work demonstrates the importance of increasing the length of the linker to avoid the quenching of the $\mathrm{Eu}(\mathrm{III})$ emission via the mannose hydroxyls. In addition, because the carbohydrate recognition domains (binding sites) of the mannose receptor also contain a large number of $\mathrm{OH}$ and $\mathrm{NH}$ quenchers $[28,29]$, this means that not only do we need to increase the distance from chelate to mannose residue but we also need to ensure the receptor itself will not quench the emission. The next stage of probe development is to increase the emission intensity by incorporating an antenna for the sensitisation of $\mathrm{Eu}$ (III) emission, as the emission intensities of complexes 1-4 were too low for efficient use as cellular imaging agents.

\section{Conflict of Interests}

The authors declare that they have no relevant or material financial interests that relate to the research described in this paper. Specifically, the authors declare there is no conflict of interests with the following companies: Chemsynlab, SigmaAldrich, or Merck.

\section{Acknowledgments}

Gratitude is extended toward the members of the Mechanisms in Cell Biology and Diseases Research Group at the University of South Australia. The authors would also like to acknowledge the University of South Australia and Australian Postgraduate Award Scholarship for funding.

\section{References}

[1] C. Penas, E. Pazos, J. L. Mascareñas, and M. E. Vázquez, "A folding-based approach for the luminescent detection of a short 
rna hairpin," Journal of the American Chemical Society, vol. 135, no. 10, pp. 3812-3814, 2013.

[2] J.-C. G. Bünzli and C. Piguet, "Taking advantage of luminescent lanthanide ions," Chemical Society Reviews, vol. 34, no. 12, pp. 1048-1077, 2005.

[3] J. S. Josan, C. R. de Silva, B. Yoo et al., "Fluorescent and lanthanide labeling for ligand screens, assays, and imaging," Methods in Molecular Biology, vol. 716, pp. 89-126, 2011.

[4] J. Reifernberger, P. Ge, and P. Selvin, "Progress in lanthanides as luminescent probes," in Reviews in Fluorescence 2005, C. Geddes and J. Lakowicz, Eds., pp. 399-431, Springer, New York, NY, USA, 2005.

[5] J.-C. G. Bünzli, "Lanthanide luminescence for biomedical analyses and imaging," Chemical Reviews, vol. 110, no. 5, pp. 27292755, 2010.

[6] J. M. Irache, H. H. Salman, C. Gamazo, and S. Espuelas, "Mannose-targeted systems for the delivery of therapeutics," Expert Opinion on Drug Delivery, vol. 5, no. 6, pp. 703-724, 2008.

[7] H. Du, M. Levine, C. Ganesa, D. P. Witte, E. S. Cole, and G. A. Grabowski, "The role of mannosylated enzyme and the mannose receptor in enzyme replacement therapy," American Journal of Human Genetics, vol. 77, no. 6, pp. 1061-1074, 2005.

[8] S. M. van Patten, H. Hughes, M. R. Huff et al., "Effect of mannose chain length on targeting of glucocerebrosidase for enzyme replacement therapy of Gaucher disease," Glycobiology, vol. 17, no. 5, pp. 467-478, 2007.

[9] S. A. Linehan, "The mannose receptor is expressed by subsets of APC in non-lymphoid organs," BMC Immunology, vol. 6, no. 1, article 4, 2005.

[10] M. A. Brimble, R. Kowalczyk, P. W. R. Harris, P. R. Dunbar, and V. J. Muir, "Synthesis of fluorescein-labelled O-mannosylated peptides as components for synthetic vaccines: comparison of two synthetic strategies," Organic and Biomolecular Chemistry, vol. 6, no. 1, pp. 112-121, 2008.

[11] V. le Cabec, L. J. Emorine, I. Toesca, C. Cougoule, and I. Maridonneau-Parini, "The human macrophage mannose receptor is not a professional phagocytic receptor," Journal of Leukocyte Biology, vol. 77, no. 6, pp. 934-943, 2005.

[12] E. A. L. Biessen, F. Noorman, M. E. Van Teijlingen et al., "Lysinebased cluster mannosides that inhibit ligand binding to the human mannose receptor at nanomolar concentration," The Journal of Biological Chemistry, vol. 271, no. 45, pp. 2802428030, 1996.

[13] B. G. Davis and M. A. Robinson, "Drug delivery systems based on sugar-macromolecule conjugates," Current Opinion in Drug Discovery and Development, vol. 5, no. 2, pp. 279-288, 2002.

[14] D. A. Moore, "Selective trialkylation of cyclen with tert-butyl bromoacetate [1,4,7,10-tetraazacyclododecane-1,4,7-triacetic acid, tri-tert-butyl ester hydrobromide]," Organic Syntheses, vol. 85 , pp. 10-14, 2008.

[15] P. Antoni, M. Malkoch, G. Vamvounis et al., "Europium confined cyclen dendrimers with photophysically active triazoles," Journal of Materials Chemistry, vol. 18, no. 22, pp. 2545-2554, 2008.

[16] T. M. Tagmose and M. Bols, "Synthesis of the 2-deoxyisomaltose analogue of acarbose by an improved route to chiral valieneamines," Chemistry-A European Journal, vol. 3, no. 3, pp. 453-462, 1997.

[17] W. Hayes, H. M. I. Osborn, S. D. Osborne, R. A. Rastall, and B. Romagnoli, "One-pot synthesis of multivalent arrays of mannose mono- and disaccharides," Tetrahedron, vol. 59, no. 40, pp. 7983-7996, 2003.
[18] A. Y. Chernyak, G. V. M. Sharma, L. O. Kononov et al., "2-azidoethyl glycosides: glycosides potentially useful for the preparation of neoglycoconjugates," Carbohydrate Research, vol. 223, pp. 303-309, 1992.

[19] P. Lebduková, P. Hermann, L. Helm et al., "Gadolinium(iii) complexes of mono- and diethyl esters of monophosphonic acid analogue of DOTA as potential MRI contrast agents: solution structures and relaxometric studies," Dalton Transactions, no. 4, pp. 493-501, 2007.

[20] R. S. Dickins, D. Parker, J. I. Bruce, and D. J. Tozer, "Correlation of optical and NMR spectral information with coordination variation for axially symmetric macrocyclic $\mathrm{Eu}(\mathrm{III})$ and $\mathrm{Yb}$ (III) complexes: axial donor polarisability determines ligand field and cation donor preference," Dalton Transactions, no. 7, pp. 1264-1271, 2003.

[21] D. Chen, Y. Wang, and M. Hong, "Lanthanide nanomaterials with photon management characteristics for photovoltaic application," Nano Energy, vol. 1, no. 1, pp. 73-90, 2012.

[22] J. J. Freeman and G. A. Crosby, "Spectra and decay times of the luminescences observed from chelated rare earth ions," The Journal of Physical Chemistry, vol. 67, no. 12, pp. 2717-2723, 1963.

[23] J. Georges and J. M. Mermet, "Simultaneous time-resolved fluorescence and thermal lens measurements: application to energy transfer studies in europium chelates," Spectrochimica Acta A, vol. 49, no. 3, pp. 397-404, 1993.

[24] M. Iwamura, Y. Kimura, R. Miyamoto, and K. Nozaki, "Chiral sensing using an achiral europium(III) complex by induced circularly polarized luminescence," Inorganic Chemistry, vol. 51, no. 7, pp. 4094-4098, 2012.

[25] S. E. Plush, N. A. Clear, J. P. Leonard, A.-M. Fanning, and T. Gunnlaugsson, "The effect on the lanthanide luminescence of structurally simple $\mathrm{Eu}(\mathrm{III})$ cyclen complexes upon deprotonation of metal bound water molecules and amide based pendant arms," Dalton Transactions, vol. 39, no. 15, pp. 3644-3652, 2010.

[26] A. J. L. Villaraza, A. Bumb, and M. W. Brechbiel, "Macromolecules, dendrimers, and nanomaterials in magnetic resonance imaging: the interplay between size, function, and pharmacokinetics," Chemical Reviews, vol. 110, no. 5, pp. 2921-2959, 2010.

[27] J. N. Kemsley, K. L. Zaleski, M. S. Chow et al., "Spectroscopic studies of the interaction of ferrous bleomycin with DNA," Journal of the American Chemical Society, vol. 125, no. 36, pp. 10810-10821, 2003.

[28] H. Feinberg, S. Park-Snyder, A. R. Kolatkar, C. T. Heise, M. E. Taylor, and W. I. Weis, "Structure of a C-type carbohydrate recognition domain from the macrophage mannose receptor," The Journal of Biological Chemistry, vol. 275, no. 28, pp. 2153921548, 2000.

[29] N. P. Mullin, P. G. Hitchen, and M. E. Taylor, "Mechanism of $\mathrm{Ca}^{2+}$ and monosaccharide binding to a C-type carbohydraterecognition domain of the macrophage mannose receptor," The Journal of Biological Chemistry, vol. 272, no. 9, pp. 5668-5681, 1997. 

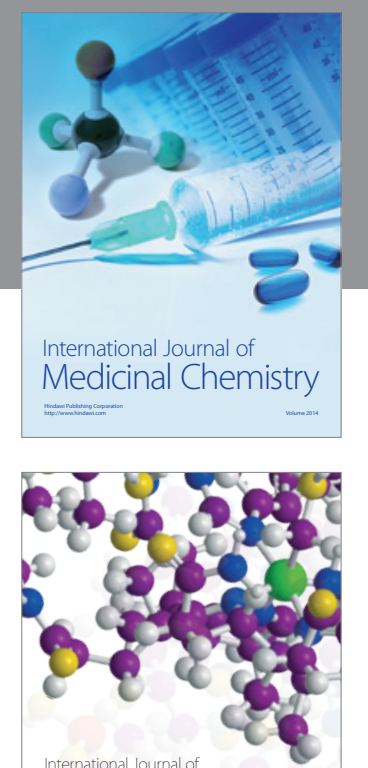

\section{Carbohydrate} Chemistry

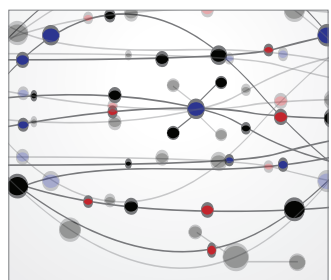

The Scientific World Journal
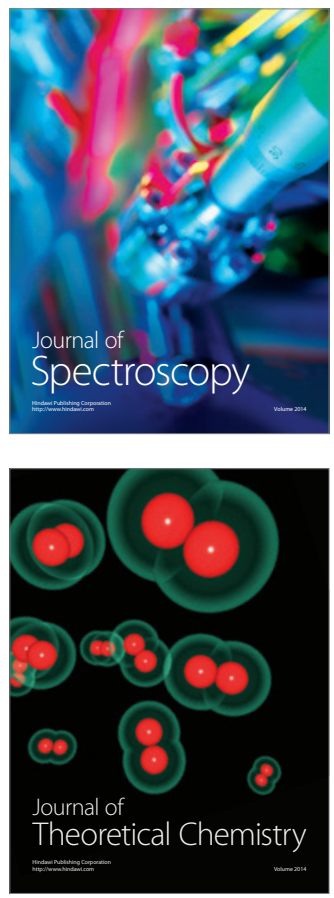
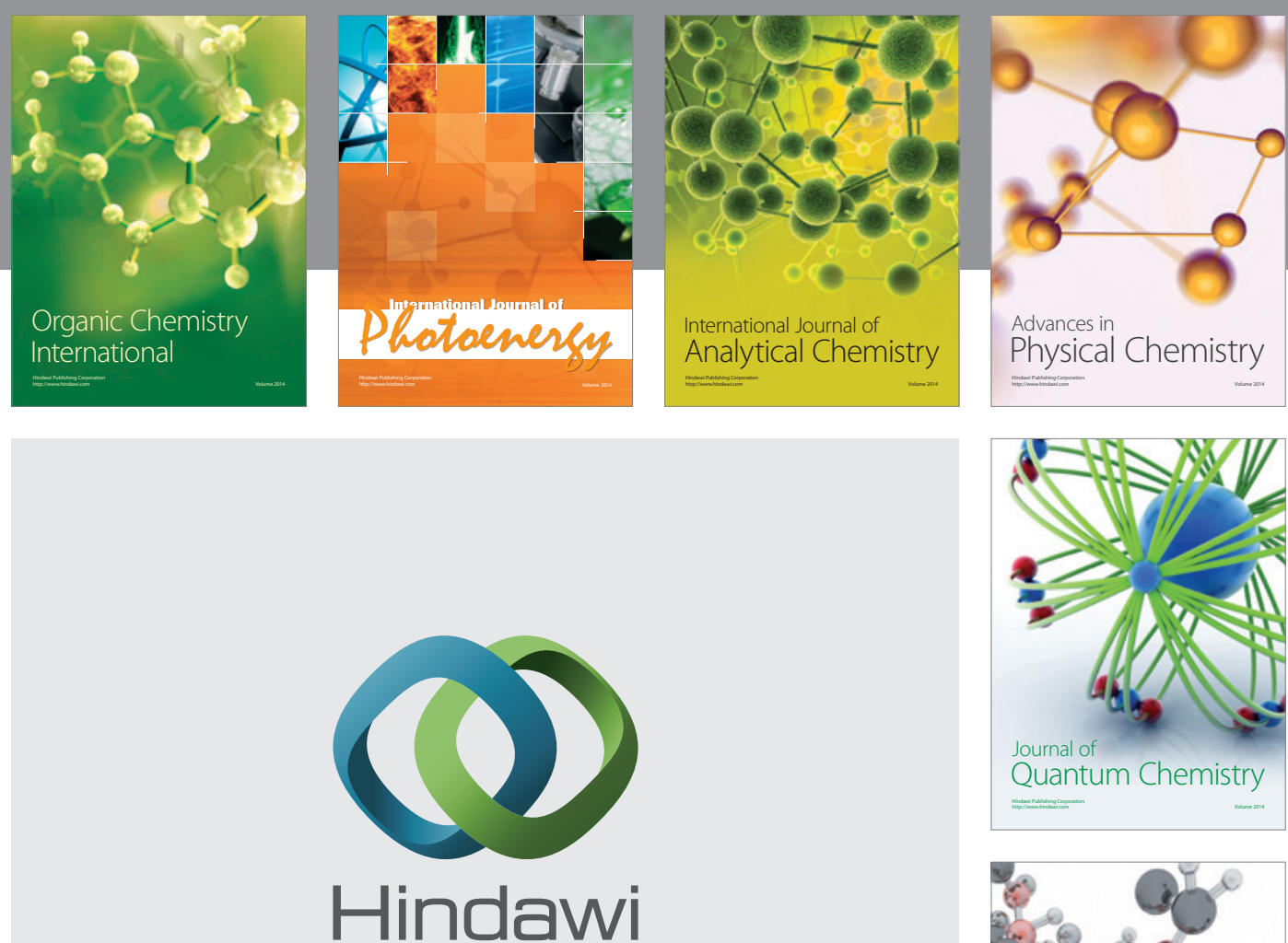

Submit your manuscripts at

http://www.hindawi.com

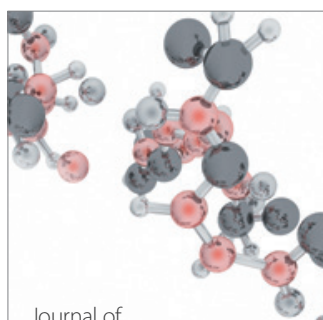

Analytical Methods

in Chemistry

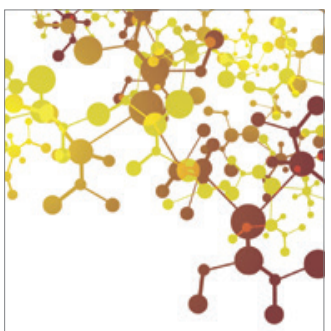

Journal of

Applied Chemistry

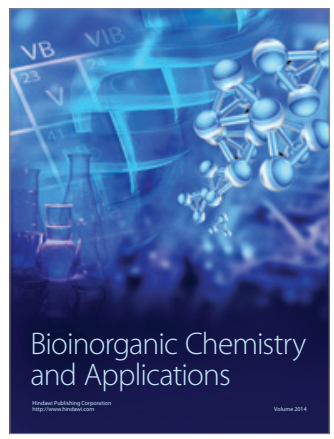

Inorganic Chemistry
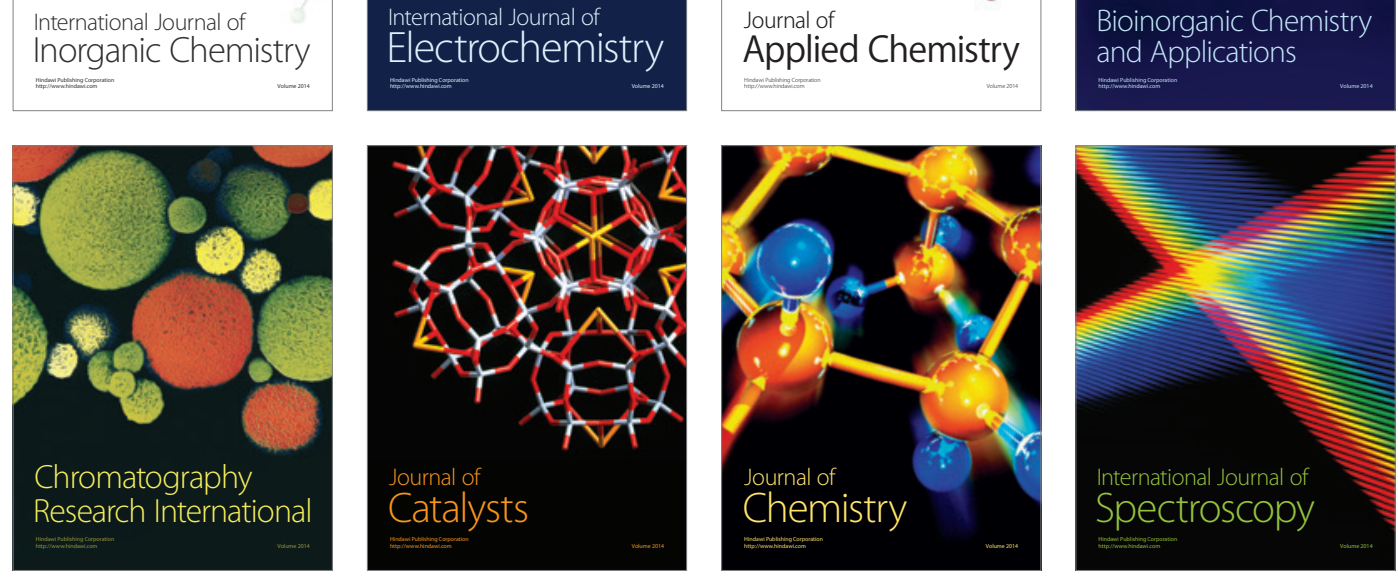